\title{
PENGELOLAAN WISATA BUDAYA PERMANDIAN AIR TERJUN BANTIMURUNG'NA GALLANG KABUPATEN GOWA PROVINSI SULAWESI SELATAN
}

\author{
Oleh: \\ I NYOMAN SIRYAYASA \\ Politeknik Pariwisata Makassar

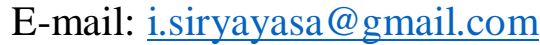

\begin{abstract}
ABSTRAK: Penelitian ini bertujuan untuk membahas masalah tentang pemanfaatan alam wisata Permandian Air Terjun Bantimurung'Na Gallang agar dapat menarik perhatian pengunjung datang ke permandian tersebut, serta adanya upaya pihak pemerintah dalam pengelolaan objek wisata tersebut termasuk memasarkan dan mempromosikan. Adapun jenis penelitian yang digunakan yaitu deskriptif kualitatif, penelitian ini menemukan berbagai fakta yang dapat diintepretasikan dalam bentuk tabel yang bermanfaat untuk menjawab segala bentuk permasalahan yang terjadi dalam penelitian ini. Hasil penelitian ini menunjukan bahwa keberadaan Wisata Permandian Air Terjun Bantimurung'Na Gallang dengan berbagai bentuk potensi yang dimilki memberi peluang yang besar untuk dikunjungi, peluang ini dapat terlaksana dengan baik jika pihak pemerintah daerah dan masyarakat bersinergi melakukan upaya pembenahan dalam bentuk pengelolaannya, disamping itu pemasaran dan promosi sangat dibutuhkan masyarakat untuk mengenal lebih dekat Permandian Air Terjun Bantimurung'Na Gallang yang jaraknya \pm 25 km dari Kota Malino Kabupaten Gowa Propinsi Sulawesi Selatan.
\end{abstract}

\section{KATA KUNCI: Pengelolaan, Wisata Budaya, Permandian Bantimurung 'Na}

ABSTRACT: This study aims to discuss the problem of exploiting the natural attractions of the Bantimurung Waterfall Na Gallang in order to attract the attention of visitors coming to the baths, as well as the efforts of the government in managing these attractions including marketing and promoting. The type of research used is descriptive qualitative, this study found various facts that can be interpreted in the form of tables that are useful for answering all forms of problems that occur in this study. The results of this study indicate that the existence of Bantimurung'Na Gallang Waterfall Bathing Tourism with various forms of potential has a great opportunity to be visited, this opportunity can be implemented well if the local government and the community work together to make improvements in the form of management, besides marketing and promotion is urgently needed by the community to get to know Bantimurung'Na Gallang Waterfall Baths \pm 25 km away from Malino City, Gowa Regency, South Sulawesi Province.

KEY WORDS: Management, Cultural Tourism, Bathing in Bantimurung 'Na

\section{PENDAHULUAN}

Kabupaten Gowa adalah salah satu Kabupaten yang ada di Sulawesi Selatan. Sektor pariwisata yang ada di Kabupaten Gowa mempunyai prospek cukup menjanjikan, dimana Kabupaten Gowa memiliki modal dasar yang cukup besar antara lain seperti potensi seni dan budaya serta potensi geografisnya yang menunjang. Kabupaten Gowa memiliki banyak daya tarik wisata budaya yang 
terkenal seperti, Benteng Somba Opu, Museum Balla Lompoa, Makam Sultan Hasanuddin, Makam Syekh Yusuf, Makam Arung Palaka, Masjid Tua Katangka dan masih banyak lagi yang lain. Namun selain daya tarik wisata budaya, Kabupaten Gowa juga terkenal dengan wisata alamnya.

Kabupaten Gowa adalah kabupaten multi potensi, bukan hanya dari sektor pertanian dan sektor pertambangan, akan tetapi juga pada sector pariwisatanya. Tak heran jika Kabupaten Gowa menjajal diri sebagai daerah destinasi sebagai event kalender nasional khususnya Beautiful Malino di Kecamatan Tinggimoncong. Sektor pariwisata di Kabupaten Gowa mempunyai prospek ke depan yang cukup cerah dan menjanjikan, dimana Kabupaten Gowa mempunyai modal dasar yang cukup besar antara lain seperti potensi seni dan budaya serta potensi geografisnya yang menunjang. Selain potensi wisata budaya Kabupaten Gowa juga akan terkenal dengan potensi wisata alamnya seperti kawasan objek wisata Malino. Potensi Malino sebagai objek wisata pun ditunjang sejumlah potensi wisata alam yang tersebar dikawasan dataran tinggi lainnya.

Pembangunan kepariwisataan di Kabupaten Gowa memiliki keanekaragaman tersendiri untuk dikembangkan baik dari segi keindahan alamnya maupun dari segi peninggalan sejarah masa lalu, hal ini merupakan salah satu kelebihan yang dimiliki Kabupaten Gowa jika dibandingkan dengan kabupaten lainnya yang terdapat di Provinsi Sulawesi Selatan, potensi yang dimiliki daerah ini dapat dilihat dengan banyaknya lokasi atau tempat tujuan wisata baik yang sudah dikelola maupun yang belum tersentuh oleh pihak pemerintah, swasta dan masyarakat termasuk juga sektor-sektor terkait lainnya yang terdapat di Kabupaten
Gowa. Adapun daerah tujuan wisata yang menjadi unggulan dimaksud sebagai berikut : (1) Air Terjun Bantimurung'Na Gallang terletak di Desa Pao Kecamatan Tombolopao, Kabupaten Gowa. Lokasinya memang cukup jauh yaitu +90 $\mathrm{km}$ dari Kota Sungguminasa dengan jarak tempuh +3 jam. (2) Air Terjun Takapala yang berada di Desa Bulutana, Kecamatan Tinggimoncong, Kabupaten Gowa, Adalah salah satu destinasi yang tidak pernah bosan dikunjungi oleh wisatawan saat berlibur di Malino. Objek wisata ini memiliki tinggi 109 meter dan dikelilingi perbukitan serta rerimbunan hutan yang menyejukkan. (3) Hutan Pinus Tinggimoncong yang berada di Kecamatan Tinggimoncong, Kabupaten Gowa, atau yang lebih dikenal dengan nama Hutan Pinus Malino yang terletak di deretan pegunungan dan lembah cocok sebagai spot kece tempat berphoto. (4) Malino Highlands berada di Pattapang, Tinggimoncong, Kabupaten Gowa. Yang dikenal dengan perkebunan teh yang merupakan peninggalan masa penjajahan Jepang ini memiliki banyak spot menarik yang dapat dinikmati pengunjung. (5) Taman Wisata Holyland Malino berada di Lonjoboko, Parangloe, Kabupaten Gowa, taman ini memiliki bangunan gedung eksotis mirip Holyland yang ada di Israel (Muljadi, 2009)

Dari sekian banyak unggulan kepariwisataan yang dipasarkan oleh pemerintah daerah maka terdapat didalamnya salah satu destinasi yang cukup menarik dan memiliki daya tarik wisata bagi masyarakat serta pemerintah daerah Kabupaten Gowa, yaitu Permandian Air Terjun Bantimurung'Na Gallang. Objek wisata ini sebagai tempat rekreasi bagi wisatawan khususnya bagi masyarakat di Desa Tombolo Pao Kecamatan Tobolopao, Kabupaten Gowa. Hal ini dilakukan pemerintah untuk dapat meningkatkan kontribusi dan memberi nilai tambah bagi masyarakat di 
sekitar destinasi khususnya kesejahteraan melalui usaha industry untuk bahan cenderamata. Dengan adanya pariwisata dapat tercipta bagi masyarakat lokal, mulai dari sebagai karyawan hotel sampai penjual pernak-pernik di daerah objek wisata. Dengan perkembangan perkembangan pariwisata tentu berpengaruh terhadap pendapatan pajak bagi daerah setempat sehingga dapat digunakan untuk memperbaiki inprastruktur, seperti meningkatkan kualitas jalan, pasar, peningkatan fasilitas layanan bagi objek wisata yang bersangkutan sehingga lebih menarik dan layak untuk dikunjungi. Peningkatan pariwisata juga dapat membantu melestarikan budaya dan kearipan lokal, karena budaya merupakan salah satu daya tarik wisata yang paling diminati oleh wisatawan asing. Oleh karena itu Permandian Air Terjun Bantimurung'Na Gallang diharapkan dapat dijadikan sebagai tempat penelitian khususnya yang berkaitan dengan masalah wisatawan bahari.

Namun sangat disayangkan karena dari hasil observasi awal yang dilakukan oleh calon peneliti menunjukkan adanya berbagai kekurangan yang terjadi baik dari segi pengelolaan secara umum maupun Penataan objek itu sendiri. Selain pelayanan dan penataan Permandian Air Terjun Bantimurung'Na Gallang yang terlihat belum ditangani secara serius pembenahan kebersihan dan keamanan yang tidak tertangani dengan baik oleh pihak pengelola, sehingga mempengaruhi jumlah kunjungan yang datang ke destinasi tersebut (Susilawati, Mappamiring, and Said 2016)

Menurut sejarah lalu bahwa kawasan air Terjun Bantimurung'Na Gallang sudah ada sejak tiga kerajaan masih berdiri di Gowa. Pada tahun 1927 tiga kerajaan berdiri di sekitar air terjun tersebut, yaitu Kerajaan Ballasuka,
Kerajaan Pao dan Kerajaan Lombo. Menurut cerita Camat Tombolopao, Baharuddin Lewa, dinamakan Bantimurung'Na Gallang dikarenakan di masa ke tiga kerajaan itu pada zaman Belanda dikawasan Air terjun tersebut dijadikan sebagai tempat eksekusi bagi warga yang melanggar hukum adat.

Topik mengenai Pengelolaan Objek Wisata Permandian Air Terjun Bantimurung'Na Gallang di Desa Pao Kecamatan Tombolo Pao Kabupaten Gowa Propinsi Sulawesi Selatan untuk dapat memberikan manfaat kepada masyarakat yang berdomisili disekitar objek wisata dan juga dapat dimanfaatkan secara luas baik wisatawan Nusantara maupun Wisatawan Mancanegara dan khususnya masyarakat sekitar.

Bertitik tolak pada latar belakang masalah, maka masalah pokok yang akan dikaji dalam penelitian ini, dirumuskan sebagai berikut: (1) Bagaimana Pengelolaan Permandian Air Terjun Bantimurung'Na Gallang (2) Faktorfaktor apa yang diperlukan untuk meningkatkan daya tarik wisata

\section{PEMBAHASAN}

Berdasarkan Undang-Undang Nomor 10 Tahun 2009 daerah tujuan pariwisata yang selanjutnya disebut Destinasi Pariwisata adalah kawasan geografis yang berada dalam satu atau lebih wilayah administratif yang di dalamnya terdapat daya tarik wisata, fasilitas umum, fasilitas pariwisata aksesibilitas, serta msyarakat yang saling terkait dan melengkapi terwujudnya kepariwisataan.

Menurut Kusdianto dalam Pitana destinasi dapat digolongkan atau dikelompokkan berdasarkan ciri-ciri destinasi tersebut, yaitu sebagai berikut: (1) Destinasi sumber daya alam, seperti iklim, pantai dan hutan. (2) Destinasi sumber daya budaya, seperti tempat 
bersejarah, museum, teater dan masyarakat lokal. (3) Fasilitas rekreasi, seperti taman hiburan. (4) Event seperti, Kesenian Bali, Pesta Danau Toba dan pasar malam. (5) Aktivitas spesifik, seperti Kasino di Genting Highland Malaysia, Wisata Belanja di Hongkong. (6) Daya tarik Psikologi, seperti, petualangan, perjalanan romantis dan keterpencilan (Burns 2003; Cohen 2004; Pitana and Diarta 2009; Rodger, Moore, and Newsome, 2009)

Destinasi merupakan suatu kawasan spesifik yang dipilih oleh seorang pengunjung ia dapat tinggal selama waktu tertentu. Kata "destinasi" dapat membingungkan juga karena digunakan untuk suatu kawasan terencana, yang sebagian atau seluruhnya dilengkapi (self-contained) dengan amenitas dan pelayanan produk wisata, fasilitas rekreasi, restoran, hotel, atraksi, hiburan, dan toko pengecer yang dibutuhkan pengunjung (Kusudianto, 1996)

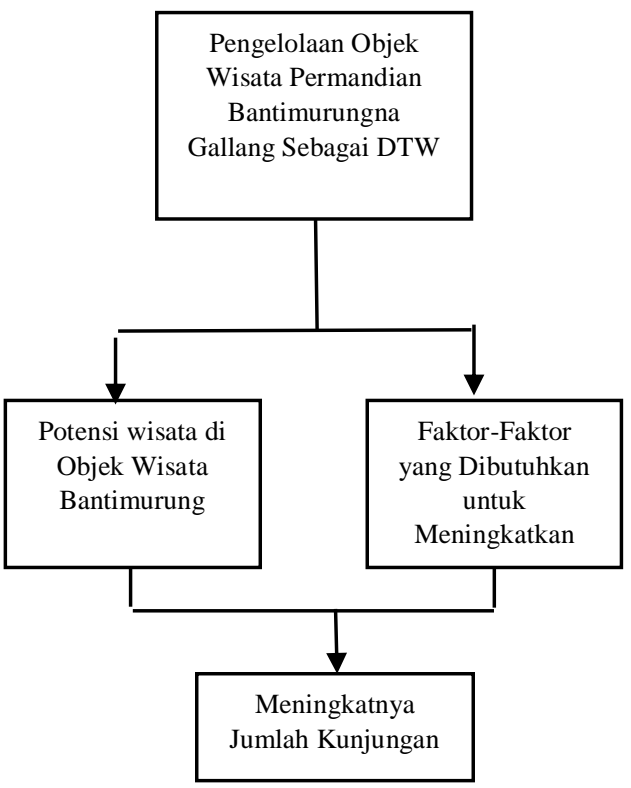

\section{Gambaran Umum Objek Penelitian}

Tombolo Pao adalah sebuah kecamatan di Kabupaten Gowa Sulawesi Selatan dengan luas wilayah keseluruhan adalah 251,82 km2 dengan jumlah pendudukan Kecamatan Tombolo Pao sebesar \pm 26.938 yang terdiri dari lakilaki sebesar \pm 13.417 jiwa dan perempuan sebesar \pm 13.521 jiwa. Kecamata Tombolo Pao dibentuk pada tahun 1998 dari hasil pemekaran Kecamatan Tinggimoncong. Wilayah kecamatan Tombolo Pao, wilayah ini berada kurang lebih $105 \mathrm{~km}$ dari kota Makassar dan memiliki batas wilayah sebagai berikut (1) Sebelah Utara

Kecamatan Sinjai Barat di Kabupaten Sinjai. (2) Sebelah Barat

Kecamatan Bontocani, di Kabupaten Bone dan Kecamatan Tanralili Kabupaten Maros. (3) Sebelah Selatan : Kecamatan Tinggimoncong.

Selain Desa Pao, di sekitarnya terdapat Desa Balassuka, yaitu suatu desa yang masih berada di wilayah Kecamatan Tombolo Pao, bagian Timur Kabupaten Gowa yang berbatasan dengan Kecamatan Sinjai Barat Kabupaten Sinjai. Kecamatan Tombolo Pao merupakan daerah pegunungan dengan curah hujan rata-rata dalam per tahun antara 135 hari sampai 160 hari dan ketinggian dari permukaan laut berkisar raa-rata 500 meter, dengan jumlah desa/kelurahan. 


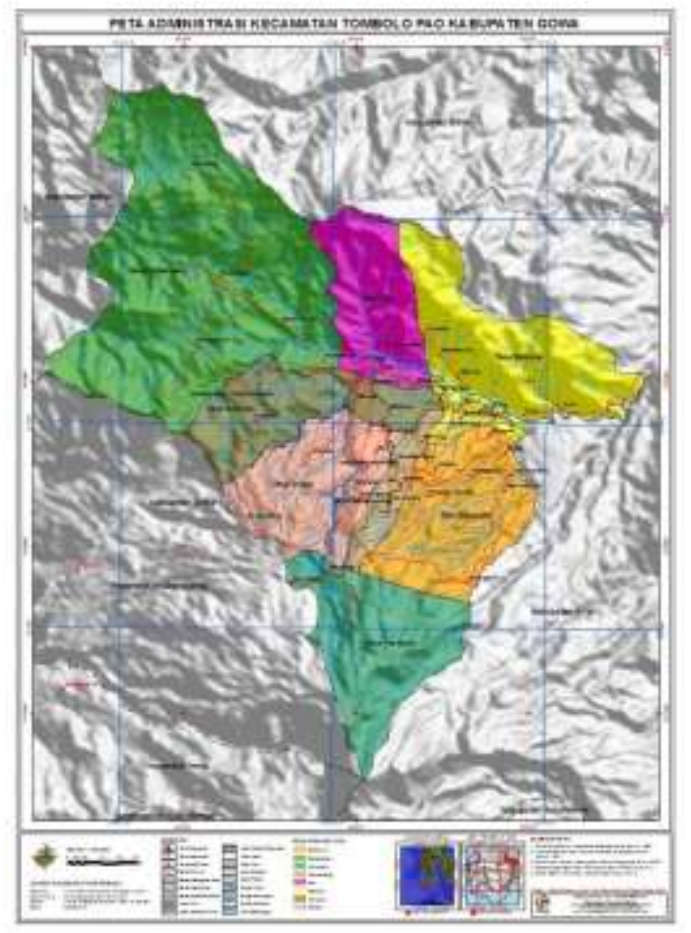

Jumlah penduduk yang tersedia pada suatu daerah merupakan potensi yang sangat menentukan perkembangan bagi daerah tersebut. Kekurangan jumlah penduduk dapat mempengaruhi jalannya proses pembangunan, sebab penduduk selain sebagai objek juga sebagai subyek pembangunan. Penduduk merupakan titik sentral faktor produksi lainnya atau sebagai motor penggerak dari factorfaktor produksi lainnya. Upaya-upaya peningkatan produktifitas penduduk telah dilakukan dengan cara pembinaan agar memiliki keterampilan sehingga dapat meningkatkan taraf hidup yang lebih baik, serta berproduksi atau mendatangkan manfaat yang tentu dengan sendirinya dapat menghasilkan kesejahteraan bagi masyarakat sekitar. Pembangunan kependudukan dilaksanakan mempertimbangkan keterkaitan dengan upaya pelestarian lingkungan hidup dan sumber daya alam, penciptaan keserasian antara generasi serta peningkatan kesejahteraan.

Selanjutnya pengendalian pertumbuhan penduduk juga dilakukan terutama untuk menurunkan angka kelahiran melalui KB (Keluarga Berencana) mandiri, menurunkan angka kematian ibu dan anak balita melalui program sayang ibu dan anak. Pengendalian jumlah perkembangan penduduk. Pengarahan tentang persebaran penduduk dengan tetap mempertimbangkan kemampuan daya dukung sumber daya alam yang ada di daerah Kecamatan Tombolo Pao terkhusus di Desa Pao, Kabupaten Gowa. Aktivitas perekonomian masyarakat di Desa Pao Kecamatan Tombolo Pao sebagian besar penduduk bermatapencaharian sebagian besar berprofesi sebgai petani sayuran dan perkebunan. Namun ada juga sebagian beralih profesi sebagai pedagang, berwiraswasta, sebagai Pegawai Negeri, juga berprofesi sebagai TNI dan POLRI maupun bekerja pada sektor swasta. Kalau dilihat dari segi pendidikan, masyarakat di Desa Pao Kecamatan Tombolo Pao tidak kalah dibandingkan dengan pendidikan masyarakat di daerah lain yang ada di Kabupaten Gowa. Namun demikian pihak pemerintah, baik daerah maupun propinsi harus tetap memberikan arahan bahwa pendidikan merupakan pilar utama untuk mencapai kesejahteraan dan mendapat pekerjaan yang layak bagi generasi penerus. Dengan adanya pengembangan pariwisata tentu akan berdampak terhadap pendapatan masyarakat serta perputaran perekonomian di daerah.

Kecamatan Tombolo Pao merupakan salah satu kecamatan yang terletak didataran tinggi di Kabupaten Gowa. Kecamatan Tombolo Pao pada ketinggian antara $1.500-1.650$ meter di atas permukaan laut dan jika ditinjau dari segi kemiringan lereng Desa Kanreapia sebagian besar berada pada kemiringan lereng $8 \%$ - $40 \%$ atau sebagian besar wilayah adalah pegunungan.

Kecamatan Tombolo Pao memiliki 9 (sembilan) desa/kampung, 
yaitu: (1) Desa Balassuka, (2) Desa Balaromang, (3) Desa Erelembang, (4) Desa Kanreapia, (5) Desa Mamamoang, (6) Desa Pao, (7) Desa Tabbinjai, (8) Desa Tamaona dan (9) Desa Tonasa

Desa Pao, Kecamatan Tombolo Pao merupakan daerah basah dengan intensitas curah hujan yang tinggi, yaitu antara 2000 - $3000 \mathrm{~mm} /$ tahun. Berbeda dengan wilayah lain yang ada di Kabupaten Gowa yang memulai musim hujan rata-rata mulai bulan Oktober. Desa Pao Kecamatan Tombolo Pao musim turun hujan rata dimulai pada bulan Mei setiap tahunnya, sehingga wilayah Tombolo Pao mempunyai suhu rata-rata sekitar $17-22{ }^{\circ} \mathrm{C}$.

Selain sebagai wilayah yang memiliki curah hujan yang tinggi dibandingkan dengan daerah lain, Desa Pao, Kecamatan Tombolo Pao juga memiliki kondisi hidrolik yang baik sebagai wilayah pertanian karena di wilayah tersebut banyak dilalui sungai baik besar maupun kecil yang juga berfungsi sebagai sumber irigasi bagi lahan pertanian penduduk. Dimana merupakan daerah basah atau lembab yang merupakan cocok sebagai daerah untuk pengembangan sektor pertanian

\section{Objek dan Daya Tarik Wisata}

Desa Pao Kecamatan Tombolo Pao adalah sebuah daerah yang ada di Kabupaten Gowa, Sulawesi Selatan. Kecamatan Tombolo Pao dibentuk pada tahun 1998 dari hasil pemekaran Kecamatan Tinggi Moncong. Kecamatan Tombolo Pao memiliki 9 (sembilan) desa, yaitu: (1) Desa Kanreapia, (2) Desa Tonasa, (3) Desa tamaona, (4) Desa Tabbinjai, (5) Desa Pao, (6) Desa Mamanpang, (7) Desa Erelembang, (8) Desa Bolaromang, dan (9) Desa Balassuka. Namun di antara sekian desa yang ada di Kecamatan Tombolo Pao yang memiliki beberapa Objek dan Daya
Tarik Wisata (ODTW) yang sangat potensial untuk dikembangkan.

\section{Potensi Daya Tarik Wisata Permandian Air Terjun Bantimurung'Na Gallang}

$\begin{array}{rrr}\text { Pemandian } & \text { Air } & \text { Terjun } \\ \text { BantimurungNa } & \text { Gallang } & \text { memiliki }\end{array}$
potensi Daya Tarik Wisata (DTW) yang sangat menjanjikan, seperti alam, budaya yang dianut oleh masyarakat Desa Pao Kecamatan Tombolo Pao. Berbagai macam potensi yang dimiliki sehingga dapat memberikan kekuatan untuk menjadi salah satu alternatif kunjungan wisata. Potensi Daya Tarik Wisata Air Terjun BantimurungNa Gallang cukup besar sekali peluangnya untuk dapat dikembangkan dan dapat diandalkan, selain keindahan dan keelokan destinasi tersebut juga berbagai alasan pengunjung datang antara lain sekedar melepas kepenatan usai beraktivitas selama sepekan. Permandian Air Terjun BantimurungNa Gallang adalah satusatunya tempat alternatif objek wisata bagi masyarakat Desa Pao Kecamatan Tombolo Pao Kabupaten Gowa sebagai tempat rekreasi. Sehingga sentuha dan pengelolaan objek wisata tersebut oleh pemerintah setempat sangat diperlukan. Tingkat kepadatan pengunjung biasanya terjadi pada akhir pekan (Sabtu dan Minggu) atau hari libur nasional namun pada kenyataannya keberadaan destinasi ini belum dapat memberikan kenyamanan secara maksimal kepada pengunjung sebagaimana objek wisata lainnya yang ada di Kabupaten Gowa. Semua ini disebabkan oleh kurangnya perhatian dan kerja sama baik dari pihak pengembang maupun dari pemerintah daerah atau stakeholder yang terkait terutama dalam hal melakukan koordinasi.

Pengembangan pariwisata Kabupaten Gowa melalui keberadaan objek wisata Air Terjun BantimurungNa 
Gallang yang terletak di Desa Pao Kecamatan Tombolo Pao merupakan hal yang sangat serius terutama dalam hal peningkatan perekonomian masyarakat sekitar.

Adapun langkah-langkah yang harus dilakukan oleh pemerintah daerah dalam melakukan pengembangan daerah ini adalah sebagai berikut: (1) Pemerintah daerah dalam hal ini Dinas Pariwisata Kabupaten Gowa harus melibatkan pihak pengembang/swasta untuk memprioritaskan pengembangan pada salah satu daerah destinasi yang tentu memiliki prospek yang menjanjikan serta strategis yaitu Objek Wisata Permandian Air Terjun BantimurungNa Gallang, karena keberadaan destinasi ini tidak terlalu jauh dari objek wisata Malino yang menjadi andalan bagi pemerintah Kabupaten Gowa bahkan sudah dikenal sampai ke mancanegara. Namun demikian, keberadaan objek wisata tersebut tidak berbanding lurus dengan manfaat yang berdampak terhadap kehidupan masyarakat sekitar. Dimana seharusnya dapat memberikan kesejahteraan terhadap masyarakat sekitar, antara lain bila pengelolaannya dilakukan dengan baik akan meningkatkan jumlah kunjungan wisatawan, sehingga dapat menciptakan lapangan kerja bagi masyarakat, penjualan hasil kerajinan, perkebunan atau hasil pertanian yang beraneka ragam. Mengingat Desa Pao merupakan lahan subur yang dimiliki oleh masyarakat yang tentu berpotensi menghasilkan buah-buahan berkualitas tinggi yang tidak akan kalah bersaing dengan daerah lain yang ada di Sulawesi Selatan. (2) Melakukan perencanaan yang matang tentang pengembangan pariwisata yang maksimal pada setiap daerah yang memiliki potensi dengan tetap mengacu pada Undang-Undang Pariwisata Nomor 10 Tahun 2009 tentang Kepariwisataan yang penjabarannya ditetapkan oleh pemerintah melalui
Peraturan Pemerintah Nomor: 50 Tahun 2011 tentang Rencana Induk Pengembangan Pariwisata Nasional. (3) Diperlukan adanya upaya dari pemerintah untuk selalu melakukan koordinasi dan kerja sama antara instansi terkait dan stakeholder dan terhadap tokoh-tokoh masyarakat yang terdapat di sekitar destinasi. (4) Akses menuju objek wisata perlu mendapat perhatian khusus dari pemerintah setempat, terutama infrastruktur jalanan dari Malino menuju Objek Wisata Air Terjun Bantimurung'Na Gallang. Disamping ketidaknyamanan pengunjung, juga sangat kemungkinan akan terjadinya kecelakaan akibat jalanan yang rusak. Jarak tempuh menjadi lebih lama, dan hal itu akan mempengaruhi minat pengunjung untuk datang berwisata (Pendit, 1994)

Namun demikian dilapangan tidak menunjukkan apa yang menjadi harapan banyak orang akan keindahan objek wisata Permandian Air Terjun Bantimurung'Na Gallang. Sebab dari hasil observasi yang dilakukan oleh peneliti memperlihatkan yang sebenarnya akan keberadaan objek wisata permandian Air Terjun BantimurungNa Gallang yang sama sekali belum tersentuh oleh pemerintah daerah dalam hal ini Dinas Pariwisata termasuk di dalamnya akan keterlibatan pihak swasta/pengembang. Dalam hal pengembangan salah satu destinasi yang ada di daerah tersebut tidak saja kita berharap akan keterlibatan pemerintah dan pihak swasta, akan tetapi peran masyarakat sekitar dan tokoh-tokoh masyarakat merupakan elemen-elemen yang sangat menunjang dan penting akan keterlibatan mereka.

Dengan belum keterlibatan pihak pemerintah, hal ini dapat dilihat dengan masih banyaknya sampah berserakan disekitar area destinasi. Sesuai pengamatan peneliti, prasarana atau 
fasilitas penunjang masih sangat minim, keindahan akan panorama alam disekitar objek wisata ini tak sebanding lurus dengan fasilitas bagi pengunjung di lokasi tersebut. Diantaranya akses jalanan untuk menuju ke lokasi objek wisata perlu ada perbaikan, masih terdapat $\pm 1 \mathrm{~km}$ pengerasan sehingga menjadi kendala untuk sampai ke objek tersebut.

Di lokasi objek wisata sudah terdapat beberapa gazebo dan satu toilet, namun jumlah tersebut tentu tidak sebanding dengan jumlah pengunjung yang datang pada saat hari libur atau pada akhir pekan. Berdasarkan hasil pengamatan peneliti, tidak ada tersedianya lokasi parkir baik kendaraan roda dua maupun kendaraan roda empat bagi pengunjung sehingga keberadaan kendaraan pengunjung juga dapat mengganggu akan keindahan lokasi objek wisata. Untuk area kolam air terjun itu sendiri masih sangat alami, namun demikian sentuhan akan keindahan baik dari pemerintah daerah maupun pihak pengelola sangat dibutuhkan untuk menampilkan serta lebih memberikan kenyamanan bagi pengunjung yang datang. Dalam hal ini perhatian pemerintah daerah semestinya lebih terfokus akan prospek yang dimiliki oleh objek wisata permandian BantimurungNa Gallang, karena dengan semakin berbenahnya objek wisata tersebut tentu akan lebih menarik minat pengunjung yang datang ke lokasi tersebut. Sehingga dengan sendirinya akan menciptakan lapangan kerja bagi masyarakat sekitar.

Berdasarkan hasil wawancara peneliti kepada mantan Kepala Desa, Desa Pao Kecamatan Tombolo Pao dua periode (2003-2014) yaitu Bapak Najamuddin (61 th) mengatakan bahwa jumlah pengunjung pada setiap hari libur mencapai \pm 150 orang yang didominasi oleh anak-anak dan orang dewasa dari berbagai daerah, baik dari masyarakat sekitar maupun dari masyarakat daerah sekitar Kecamatan Tombolo Pao. Pengunjung yang berasal dari luar masyarakat sekitar akan dikenakan retribusi bagi yang hanya menggunakan kendaraan baik kendaraan roda dua maupun kendaraan roda 4 sebesar Rp. 2.500. Masih berdasarkan keterangan mantan kepala desa, dari pihak pemerintah daerah pernah dijanjikan perbaikan jalan menuju ke objek wisata, namun sampai saat ini janji tersebut belum terealisasi. Mengenai bangunan PLTA yang ada disekitar area kawasan objek wisata merupakan lahan milik sendiri dari pihak perusahaan Bosowa. Lahan tersebut diperoleh langsung dari masyarakat yang menjualnya, oleh mantan kepala desa yaitu Bapak Najamuddin pada saat itu tidak bisa berbuat banyak untuk melarang masyarakat menjual lahannya kepada pihak perusahaan yaitu PT Bosowa, sehingga dapat mempersempit area objek wisata Air Terjun BantimurungNa Gallang. Bagi masyarakat sebagai pemilik lahan tentu dengan bebasnya serta kepada siapapun menjualnya dengan harapan memperoleh keuntungan yang diinginkan.

Di satu sisi luas area objek wisata BantimurungNa Gallang sangat sempit, melainkan hanya sebatas aliran sungai kecil yang ada di sekitar area objek wisata tersebut. Oleh pemerintah setempat, kepala desa pada saat itu (Bapak Najamuddin) sudah berkali-kali mengajukan proposal penataan dan perluasan area disekitar objek wisata tersebut dengan harapan agar lebih representatif namun sampai saat akhir masa jabatan sebagai kepala desa, bahkan sampai saat ini belum ada respon dari pemerintah setempat.

Di satu sisi kebutuhan akan pasokan listrik terhadap kebutuhan masyarakat Kecamatan Tombolo Pao Kabupaten Gowa juga tidak kalah 
pentingnya. Namun demikian dari segi estetika kurang tepat apabila keberadaan PLTA berada disekitar kawasan objek wisata, karena akan mengganggu terhadap kenyamanan pengunjung dengan suara keras yang ditimbulkannya. Masih menurut penjelasan Bapak Najamuddin, mantan kepala desa bahwa dulu pembangunan akses jalanan yang menuju ke kawasan objek wisata bukan dibangun dengan anggaran pemerintah daerah, melainkan dibangun berdasarkan bantuan swadaya masyarakat. Sehingga dengan bantuan seadanya dari masyarakat pembangunan jalanan yang menuju kawasan objek wisata tidak maksimal, sebagaimana layaknya akses jalanan yang layak dilalui, baik kendaraan roda dua maupun kendaraan roda empat, sehingga akan berpengaruh tingkat kunjungan wisatawan yang berkeinginan berwisata ke Air Terjun BantumurungNa Gallang.

Selain melakukan wawancara dengan mantan Kepala Desa Pao, peneliti juga melakukan wawancara dengan Sekretaris Dinas Pariwisata dan Olah raga Kabupaten Gowa Ibu Rahmawati, SS.M.Ed. (44 th). Mengatakan bahwa pengelolaan dan penataan objek wisata di Kabupaten Gowa, terkhusus objek wisata Permandian BantimurungNa Gallang berdasarkan skala priorias. Karena pengelolaan kawasan pariwisata merupakan pengembangan yang sifatnya terintegrasi dimana harus melibatkan banyak pihak/instansi terkait, antara lain: harus melibatkan Kementerian Pekerjaan Umum yang menangani akses menuju ke objek wisata, dan lain-lain. Mengingat bukan saja dinas pariwisata yang mempunyai kepentingan di dalamnya. Dua tahun terakhir perencanaan dan anggaran sudah diusulkan oleh pihak Dinas Pariwisata Kabupaten Gowa tentang pengelolaan objek wisata permandian Bantimurung'Na Gallang.
Namun dari pihak pemerintah Kabupaten Gowa masih lebih memprioritas kebutuhan dasar pokok masyarakat, yaitu kebutuhan akan kesehatan dan kebutuhan pendidikan yang layak bagi anak-anak usia sekolah, dan semua program prioritas tersebut gratis dengan anggaran yang cukup besar, sehingga berdampak terhadap pengelolaan dan penataan objek wisata yang ada di Kabupaten Gowa. Dalam hal ini tentu pihak pemerintah punya keterbatasan baik dari segi anggaran maupun SDM dalam hal pengelolaan kawasan pariwisata, sehingga sekian banyak objek wisata yang ada di Kabupaten Gowa tidak akan terakomodir secara bersamaan namun akan bertahap dalam pengelolaannya. Masih menurut keterangan dari Sekretaris Dinas Pariwisata Kabupaten Gowa, bahwa mengenai bangunan PLTA yang terletak di sekitar area Permandian Air Terjun BantimurungNa Gallang pihak pemerintah khususnya Dinas Pariwisata tidak bisa berbuat banyak, karena lahan yang dibangun adalah tanah milik masyarakat, sehingga masyarakat sebagai pemilik lahan bebas menjualnya kemana saja dengan pertimbangan harga yang menguntungkan. Hal inilah yang tidak terantisipasi sebelumnya oleh pemerintah setempat, sehingga dalam perencanaannya ke depan tentu akan terhambat oleh lahan yang tidak cukup tersedia. Karena tidak terkelolanya dengan baik sehingga ada beberapa oknum melakukan pungutan liar yang sudah barang tentu pendapatan tersebut tidak menjadi pendapatan daerah, yang semestinya oleh pemerintah daerah dapat dikelola untuk pengelolaan kawasan objek wisata tersebut.

Pengelolaan objek wisata permandian BantimurungNa Gallang yang baik akan berdampak positif bagi perekonomian masyarakat sekitar. Oleh 
karena itu masyarakat sekitar juga turut dilibatkan.

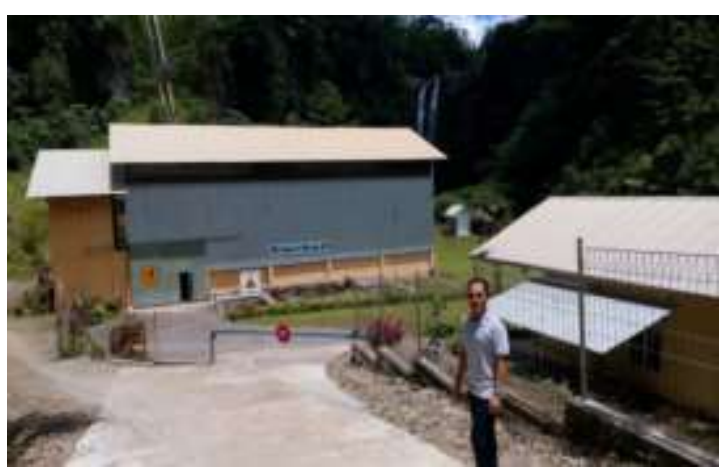

Gambar 1.1: Kondisi objek wisata Air Terjun Bantimurung'Na Gallang yang terhalang oleh bangunan PLTA yang dapat mempengaruhi keindahan dan kenyamanan

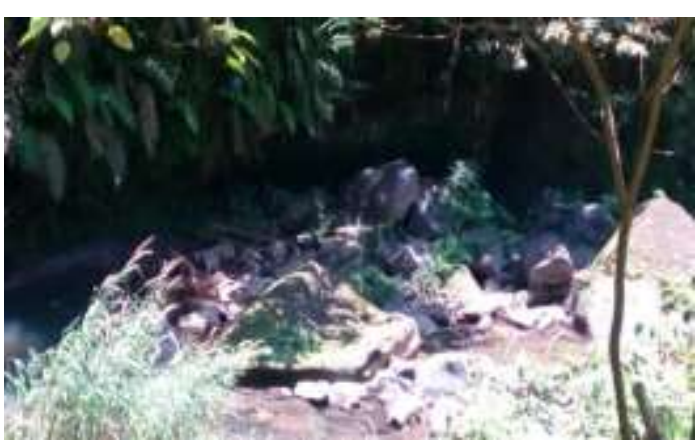

Gambar 1.2: Aliran sungai kecil yang ada di disekitar Air Terjun Bantimurung’Na Gallang

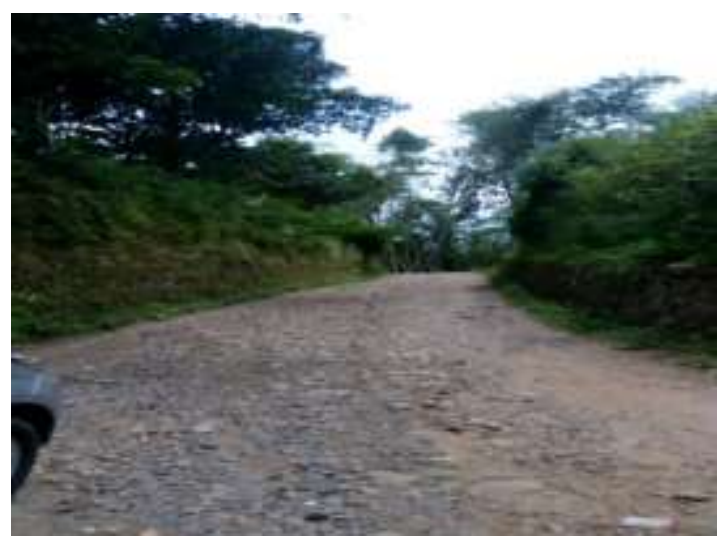

Gambar 1.3: Kondisi jalanan menuju ke objek wisata Bantimurung'Na Gallang

\section{PENUTUP}

Kawasan objek wisata permandian Air Terjun Bantimurung'Na Gallang Desa Pao Kecamatan Tombolo Pao Kabupaten Gowa memiliki potensi yang sangat menjanjikan untuk dikembangkan. Objek kawasan permandian Air Terjun Bantimurung'Na Gallang belum tersentuh sama sekali oleh pemerintah Kabupaten Gowa, sehingga dalam pengelolaannya hanya dilakukan seadanya oleh masyarakat sekitar. Pemerintah daerah Kabupaten Gowa sama sekali belum memprioritaskan dalam hal pengembangan dan penganggaran tentang pengelolaan kawasan objek wisata Air Terjun Bantimurung'Na Gallang, sehingga dampak perekonomian terhadap masyarakat sekitar tidak maksimal

Perlu adanya identifikasi objek wisata di daerah Kabupaten Gowa yang memiliki prospek menjanjikan sehingga pemerintah daerah bisa membuat kebijakan dalam hal pengembangan dan pengelolaan kawasan Permandian Air Terjun Bantimurung'Na Gallang. Peningkatan Sumber Daya Manusia dibidang pariwisata, serta melaksanakan sosialisasi terhadap masyarakat agar dalam hal pengelolaan destinasi menjadi lebih professional, sehingga dapat meningkatkan taraf hidup masyarakat disekitar destinasi pariwisata. Dalam hal pengelolaan destinasi pariwisata baik pihak swasta atau pengembang maupun pemerintah Kabupaten Gowa perlu memperhatikan fasilitas pendukung seperti pembangunan jalanan, fasilitas lainnya untuk kenyamanan pengunjung, meningkatkan promosi baik melalui media cetak maupun elektronik sehingga dapat diketahui oleh masyarakat lokal maupun nasional 


\section{DAFTAR PUSTAKA}

Burns, Peter. 2003. An Introduction to Tourism and Anthropology. Routledge

Cohen, Erik. 2004. Contemporary Tourism: Diversity and Change. Vol. 8. Elsevier Amsterdam.

Kusudianto, Hadinoto. 1996. "Perencanaan Pengembangan Destinasi Pariwisata, UI-Press."

uljadi, A. J. 2009. Kepariwisataan Dan Perjalanan. Rajawali Press.

Pendit, Nyoman S. 1994. "Ilmu Pariwisata Sebuah Pengantar." Jakarta: Pradnya Paramita.

Pitana, I. Gede and I. Ketut Surya Diarta. 2009. "Pengantar Ilmu Pariwisata. Yogyakarta."

Rodger, Kate, Susan A. Moore, and David Newsome. 2009. "Wildlife Tourism, Science and Actor Network Theory." Annals of Tourism Research 36 (4):64566.

Burns, Peter. 2003. An Introduction to Tourism and Anthropology. Routledge.

Cohen, Erik. 2004. Contemporary Tourism: Diversity and Change. Vol. 8. Elsevier Amsterdam.

Kusudianto, Hadinoto. 1996. "Perencanaan Pengembangan Destinasi Pariwisata, UI-Press."

Muljadi, A. J. 2009. Kepariwisataan Dan Perjalanan. Rajawali Press.

Pendit, Nyoman S. 1994. "Ilmu Pariwisata Sebuah Pengantar." Jakarta: Pradnya Paramita.

Pitana, I. Gede and I. Ketut Surya Diarta. 2009. "Pengantar Ilmu Pariwisata. Yogyakarta."

Rodger, Kate, Susan A. Moore, and David Newsome. 2009. "Wildlife Tourism, Science and Actor Network Theory." Annals of Tourism Research 36 (4): 64566.
Susilawati, Mappamiring, \& Alimuddin Said. 2016. "Strategi Pengembangan Pariwisata Pantai Bira Sebagaisumber Unggulan Pendapatan Asli di Daerah Kabupaten Bulukumba." Kolaborasi: Jurnal Administrasi Publik 2 (3):35 - 66 